\title{
Antigenic Differences between the Ends and Shafts of Sex Pili
}

\author{
By ELINOR MEYNELL,* R. A. MATTHEWS $\dagger$ AND A. M. LAWN \\ The Lister Institute of Preventive Medicine, Chelsea Bridge Road, \\ London $S W_{\mathrm{I}} W 8 R H$
}

(Received 13 December I973)

The sex pili determined by $\mathrm{F}$ and other bacterial sex factors are filaments formed by the ordered assembly of protein subunits (Brinton, 197I). It has been shown that the shaft of the pilus serves to attach isometric donor-specific phages (Crawford \& Gesteland, 1964) while one end contains the site of attachment for filamentous phages (Caro \& Schnös, 1966). Thus, functionally important structural differences exist between the portions of the subunits exposed at the shaft and those exposed at the tip. These structural differences might be expected to give rise to antigenic differences. Antibody reactions with sex pili have been observed directly by electron microscopy (Lawn \& Meynell, 1970), but when unpurified anti-pilus sera were used the high concentration of antibody molecules attaching to the sides of the pili prevented the detection of reactions with the tip. However, in one instance when an antiserum to an I-like sex pilus was tested after partial absorption with homologous pili, accumulations of antibody were seen at the ends of the pili with only an occasional antibody molecule attached to the shafts. It was therefore assumed that this antiserum fortuitously contained an exceptionally high concentration of antibody specific for pilus ends.

Prompted by this observation, a deliberate attempt was made to produce an antiserum preferentially enriched for end-specific antibody. A partially purified sex pilus concentrate was prepared from a strain of Escherichia coli KI 2 carrying a hybrid sex factor, F/R IdrdI 9 , which determined sex pili whose shafts were of the F serotype. The sex pili of this concentrate were broken into short fragments by sonication, which increased the number of exposed pilus ends relative to the total length of pilus shaft. This sonicated material was mixed with complete Freund's adjuvant and used to immunise two rabbits. The anti-pilus activity of the immune sera from these rabbits was progressively removed by repeated absorption with suspensions of bacteria bearing long intact pili. A preferential absorption of antibody with affinity for the pilus shaft was expected because there were few pilus ends relative to the length of shaft in these suspensions.

Using this method, an end-specific reaction was obtained with the serum from one of the two rabbits. Antibody could be seen deposited at the ends of isolated pili a short time after mixing, and agglutination between the ends of pili occurred after several hours so that the pili formed stars (Fig. I). At higher magnification, individual antibody molecules could be distinguished at the ends of the pili with almost none present on the shafts (Fig. 2).

The hybrid sex factor F/RIdrdI 9 was chosen for preparing end-specific serum because it shares characters of both F and RIdrdI9 (M. Cooke and E. Meynell, unpublished), having inherited the $\mathrm{F}$ antigenic specificity of the pilus shaft but resembling $\mathrm{R} I d r d \mathrm{I} 9$ in respect of both exclusion and degree of sensitivity to the filamentous phage $\mathrm{MI}_{3}$ which adsorbs to the

* Present address: Biological Laboratory, University of Kent, Canterbury, Kent.

$\dagger$ Present address: Department of Plant Science, Leeds University, Leeds LS2 9JT. 

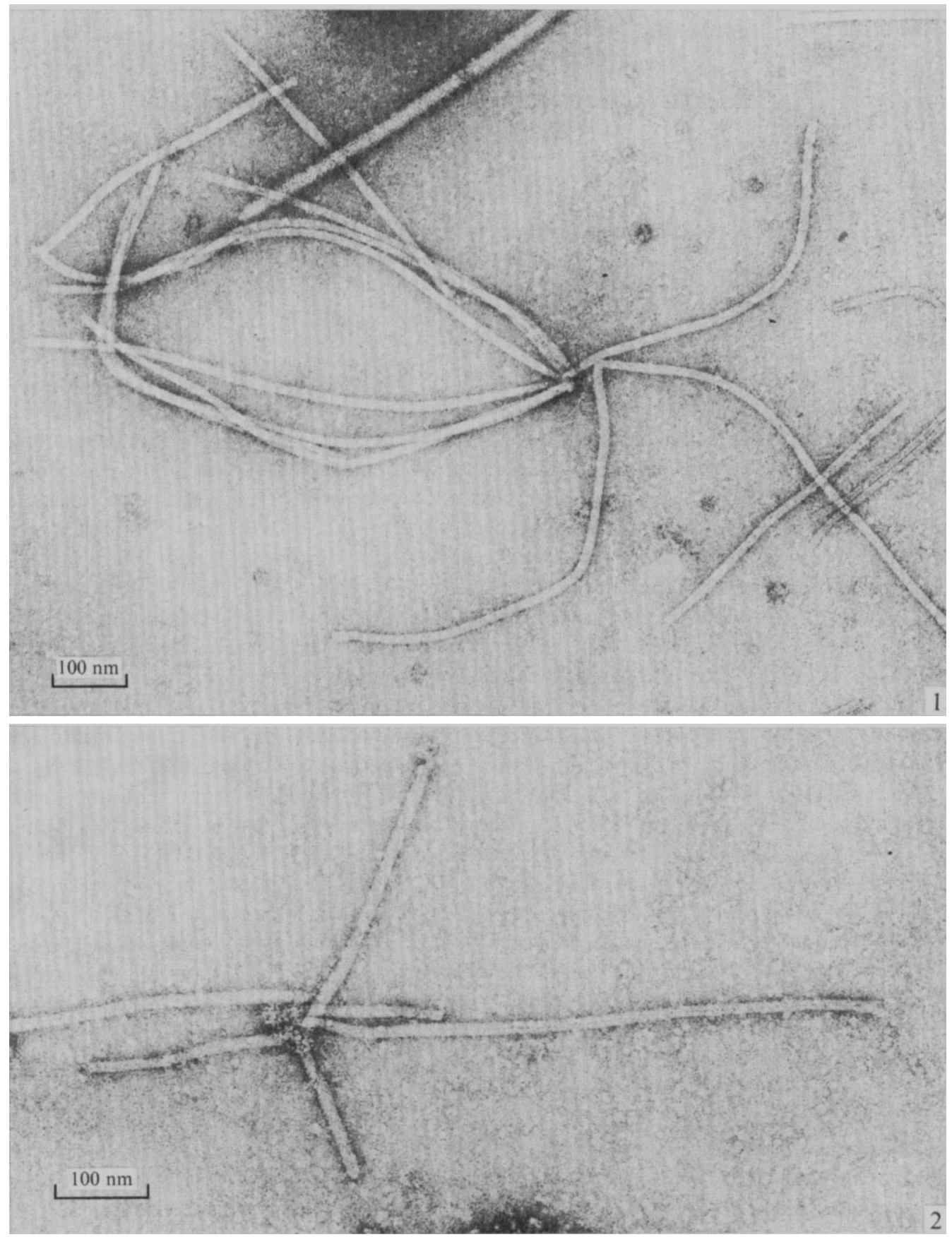

Fig. I. Agglutination between the ends of sex pili caused by their reaction with end-specific antibody. Equal parts of a sonicated sex pilus suspension and a $\mathrm{I}$ : ro dilution of the absorbed antiserum were mixed and left at $4{ }^{\circ} \mathrm{C}$ overnight. A sample was prepared for electron microscopy as previously described (Lawn \& Meynell, I970).

Fig. 2. Antibody molecules can be seen joining the ends of these sex pili, prepared as described in the legend to Fig. I. 
pilus tip. These properties might indicate the presence of RIdrdI9-like specificity in a portion of the pilus subunit other than that exposed at the shaft. The experiments described here looked for RIdrdI9 specificity at the tips of F/R IdrdI9 pili by comparing the effects of absorption with $F$ and $F / R I d r d I 9$ pili on the reaction of the serum with $F$ and $F / R I d r d I 9$ pili. However, in this respect the results were ambiguous for, although tip-specific antibody was detected, a clear distinction between the tips of F/RIdrdI9 and F pili could not be obtained.

E.M. is grateful to the Medical Research Council for financial support.

\section{REFERENCES}

Brinton, C. C. (197I). The properties of sex pili, the viral nature of 'conjugal' genetic transfer systems, and some possible approaches to the control of bacterial drug resistance. Critical Reviews of Microbiology I, I05-I60.

CARo, L. G. \& SCHNös, M. (I966). The attachment of the male-specific bacteriophage fi to sensitive strains of Escherichia coli. Proceedings of the National Academy of Sciences of the United States of America 56, I26-I32.

Crawford, E. M. \& Gesteland, R. F. (1964). The adsorption of bacteriophage R-I 7. Virology 22, I65-167.

LAwn, A. M. \& MeYnell, E. (1970). Serotypes of sex pili. Journal of Hygiene 68, 683-694. 